\title{
Pneumatised Inferior Turbinate (Pit): a "Pit" Fall for the Unwary Radiologist
}

\author{
Uma Chillalshetti ${ }^{1 *}$, Veena Kalmath ${ }^{2}$ and Sandeep Jakhere ${ }^{2}$ \\ ${ }^{1}$ Professor, Department of Radiology, Chatrapati Shivaji Maharaj Hospital and Rajiv Gandhi Medical College ,India \\ ${ }^{2}$ Associate Professor, Chatrapati Shivaji Maharaj Hospital and Rajiv Gandhi Medical College, India
}

Received date: December 20, 2017; Published date: January 31, 2018

*Corresponding author: Uma Chillalshetti, Department of Radiology, Chatrapati Shivaji Maharaj Hospital and Rajiv Gandhi Medical college, Mumbai, India, Email: umachillalshetti1@gmail.com

\begin{abstract}
Pneumatisation of the inferior turbinate is an extremely rare intranasal anatomical variant with less than 50 cases published till date. Nonetheless, it is an important anatomical variation that can cause nasal obstruction and is predisposed to similar inflammatory disorders as the rest of the nasal cavity. Accumulation of secretions with secondary infections and mucocoele formation are some of the complications that can occur. During FESS only the mucosal surface of the inferior turbinate is seen and a pneumatised inferior turbinate may be easily mistaken for a hypertrophied inferior turbinate. Computed tomography can easily diagnose a pneumatised inferior turbinate by demonstrating an air cell inside the inferior turbinate. Because of the extreme rarity of this condition there is a dearth of literature and lack of awareness among the practising and trainee radiologists. We present a case of a 14 year old boy with nasal obstruction and a pneumatised inferior turbinate.
\end{abstract}

Keywords: Pneumatised; Inferior; Turbinate

\section{Introduction}

With the advent and popularisation of Functional Endoscopic Sinus Surgery (FESS) over the last decade, pre operative Computed Tomography (CT) of the paranasal sinuses has gained utmost importance. Of particular interest have been the normal anatomic variations in the paranasal region that may sometimes be a source of difficulty during surgery or act as pre disposing factors for sinusitis.

Pneumatisation of turbinates is one such anatomical variant defined by presence of an air cell within a nasal turbinate which is lined by a similar epithelium as the rest of the sinonasal cavity. Pneumatisation is most commonly found in the middle turbinate followed by the superior turbinate. Pneumatisation of the inferior turbinate is an extremely rare intranasal anatomical variant with less than 50 cases published till date [1]. Consequently the awareness regarding this uncommon but important variant is relatively low among the practising and trainee radiologists.

\section{Case History}

A 14 year old male was referred for CT of the paranasal sinuses. He complained of recurrent bilateral nasal obstruction and discharge (more soon the right side) for the last 3 years. Symptomatic relief was obtained with decongestants; however the symptoms recurred at an interval of approximately 2-3 months. Coronal CT scan showed pneumatisation of the right inferior turbinate Figure 1. Which was confirmed by comparing with axial sections Figure 2 Additionally pneumatisation of bilateral middle turbinates was also seen Figure 1. A small polyp was also found in the right maxillary sinus.

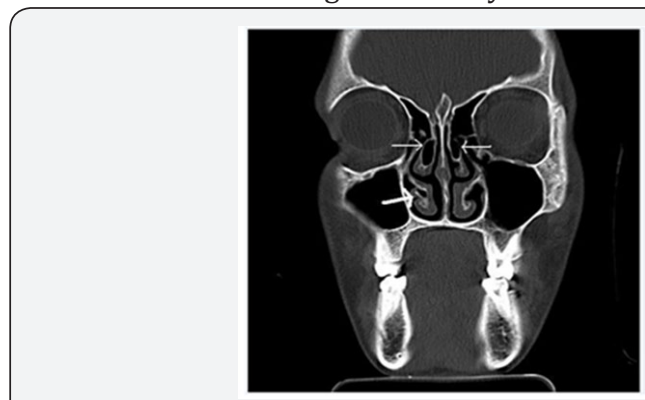

Figure 1: Coronal CT scan showing pneumatisation of the right inferior turbinate ( thick arrow).In addition pneumatisation of bilateral middle turbinates is also seen.(thin arrows)

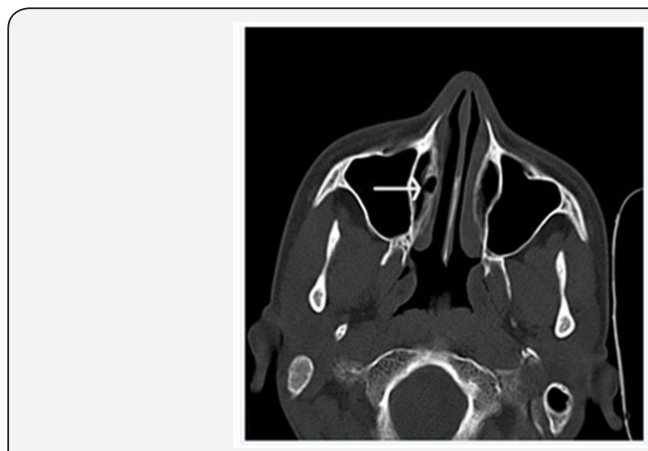

Figure 2: Axial CT scan showing a pneumatised inferior turbinate (thin arrow). 


\section{Current Trends in Clinical \& Medical Imaging}

\section{Discussion}

The first anatomical description of pneumatisation of middle turbinate was given by Emil Zuckerkandl from Austria in 1882 [2]. He stated that "Often one can detect a mutation of the anterior part of the middle turbinate into a bubble which was already described by Santorinus in his Observationes Anatomicae in 1739" [3].

Pneumatisation of the middle turbinate is a fairly common condition. Bolger et al. [4] found pneumatisation of the vertical lamella of middle turbinate in $46.2 \%$, of the inferior or bulbous segment in $31.2 \%$ and extensive pneumatisation of both the lamellar and the bulbous portion in $15.7 \%$. van Alyea [5] described an incidence of $57 \%$ for the pneumatised superior turbinate.

Pneumatisation of the inferior turbinate was first described as an anatomical variant by Zinreich et al. [6]. Most of the cases published since are mostly single case reports with the largest case series reported by Ozturk et al. [7] and Yang et al. [1] with 10 and 16 cases respectively. Yang et al. [1] reviewed 59238 sinonasal CT scans between Aug 1995 and April 2007 and found 16 patients with PIT giving an incidence of $0.03 \%$ with a male preponderance [ $56 \%$ males vs $44 \%$ females]. They reviewed the English language literature for PIT and found 28 cases reported prior to their publication taking the total number of case reports to 44 . We reviewed the English language literature and found 4 additional case reports of PIT [8-11] reported since then taking the total count to 48 .

There are usually three nasal turbinate's in the lateral nasal wall and are labelled as superior, middle and inferior according to their location. Occasionally there might be a fourth supreme turbinate. The supreme, superior and the middle turbinate's are parts of the ethmoid bone, however the inferior turbinate is a separate bone itself. Nasal turbinate's are important structures that contribute towards warming, humidification and filtration of the inspired air. In addition the anterior part of the inferior nasal turbinate contributes to the formation of the nasal valve which controls the airflow through the nasal cavity by shrinking and swelling, thereby, performing an important function in the formation of the nasal cycle. At inspiration, up to two third of the upper airway resistance is produced by the inferior nasal turbinate in the region of the nasal valve [12]. Small changes in the size and shape of the inferior turbinate can significantly affect the nasal airflow. According to Poiseuille Law flow through a tube is proportional to the fourth power of the radius or to the square of the cross sectional area [13]. Enlargement of the soft tissue or bony component of the inferior turbinate decreases the cross sectional area of the nasal airway tube and causes nasal obstruction.

In general, PIT is found as an incidental finding in an asymptomatic patient. However a large PIT can significantly reduce the nasal valve cross sectional area and cause obstructive symptoms as in our case. Similarly a large PIT can obstruct the nasolacrimal duct and cause epiphora. A PIT is lined by a similar epithelium as the rest of the paranasal sinus cavity and is therefore prone to similar inflammatory disorders. Obstruction of the drainage of a PIT can lead to accumulation of secretions with secondary infection or mucocoele formation.

During FESS only the mucosal surface of the inferior turbinate is seen and a PIT may be misdiagnosed as a hypertrophied inferior turbinate. A CT scan can readily diagnose a PIT by demonstrating an air cell within the inferior turbinate. However, radiologist should be aware of conditions that can mimic PIT including a prominent nasolacrimal duct with air, accessory lacrimal canal, normal air space between a excessively curved inferior turbinate and lateral nasal wall and excessive inferior extension of the ethmoid infundibulum [1]. In such circumstances comparison with axial CT sections is useful.

\section{Conclusion}

In conclusion, pneumatised inferior turbinate is an extremely uncommon but important anatomical variant which should be actively sought for when reviewing CT of paranasal sinuses as they are treatable causes of nasal obstruction. As of today there is a dearth of literature regarding this condition but as the awareness increases among the radiologist and otolaryngologists , this condition will be diagnosed and treated more often and add up to a substantial body of evidence to formulate treatment strategies.

\section{References}

1. Yang B, Chong V, Wang Z, Xian J, Chen Q (2008) CT appearance of pneumatized inferior turbinate. Clinical Radiology 63(8): 901-905.

2. Zuckerkand IE (1882) Normale und pathologische Anatomie der Nasenhohle und ihrer neumatischen Anhange Wien: Wilhelm Braumuller, Netherlands.

3. Santorini DJ (1882) Observationes anatomicae. Cited in Zuckerkandl E. Normale und pathologische Anatomie der Nasenhohle und ihrer pneumatischen Anhange. Wien: Wilhelm Braumuller 1739: 88-89.

4. Bolger WE, Clifford A, Butzin A, Parson DS (1991) Paranasal sinus bony anatomic variations and mucosal abnormalities: CT analysis for endoscopic sinus surgery. Laryngoscope 101(1 Pt 1): 56-64.

5. van Alyea OE (1939) Ethmoid labyrinth. Arch Otolaryngol 29(6): 881902.

6. Zinreich SJ, Mattox DE, Kennedy DW, Chisholm HL, Diffley DM, et al. (1988) Concha bullosa: CT evaluation. J Comput Assist Tomogr 12(5): 778-784.

7. Oztürk A, Alatas N, Oztürk E, San I, Sirmatel O, et al. (2005) Pneumatization of the inferior turbinates: incidence and radiologic appearance. J Comput Assist Tomogr 29(3): 311-314.

8. Neskey D, Eloy J, Casiano RR (2009) Nasal Septal, and Turbinate Anatomy and Embryology. Otolaryngol Clin North Am 42(2): 193-205.

9. Eweiss A, Khatwa MM, Zeitoun H (2008) Trifurcate middle turbi- nate; an unusual anatomical variation. Rhinology 46(3): 246-248.

10. Kiroglu AF, Cankaya H, Yuca K, Kara T, Kiris M (2007) Isolated turbinitis and pneumatization of the concha inferior in a child. Am J Otolaryngol 28(1): 67-68.

11. Ozcan KM, Selcuk A, Ozcan I, Akdogan O, Dere H (2008) Anatomical variations of nasal turbinates. J Craniofac Surg 19(6): 1678-1682. 


\section{Current Trends in Clinical \& Medical Imaging}

12. Rohrich RJ, Krueger JK, Adams WP, Marple BF (2001) Rationale for submucous resection of hypertrophied inferior turbinates in rhinoplasty: an evolution. Plast Reconstr Surg 108(2): 536-544.

13. Powell NB, Zonato AI, Weaver EM, Li K, Troell R, et al. (2001) Radiofrequency treatment of turbinate hypertrophy in subjects using

DOI: 10.19080/CTCMI.2018.02.555585 continuous positive airway pressure: a randomized, double-blind, placebo-controlled clinical pilot trial. Laryngoscope 111(10): 17831790.

\section{Your next submission with Juniper Publishers will reach you the below assets}

- Quality Editorial service

- Swift Peer Review

- Reprints availability

- E-prints Service

- Manuscript Podcast for convenient understanding

- Global attainment for your research

- Manuscript accessibility in different formats ( Pdf, E-pub, Full Text, Audio)

- Unceasing customer service

Track the below URL for one-step submission https://juniperpublishers.com/online-submission.php 